\title{
ERDŐGAZDÁLKODÁS ÉS LOGISZTIKA
}

\author{
Harangi-Rákos Mónika - Oláh Judit - Antal Gabriella - Fróna Dániel
}

\begin{abstract}
Az erdő először otthont adott az embernek, aki később felismerte hasznosságát, használhatóságát. A faanyag végigkíséri az embert élete útján, egészen a bölcsőtől a sírig. A fa a ma használatos természetes és mesterséges anyagok korában még mindig jelentős szereppel bír. Kutatásunk célja az volt, hogy bemutassuk egy erdőgazdálkodással foglalkozó vállalkozás gazdálkodását, valamint a logisztikai funkciók müködésének hatékonyságát. Mint állami erdőgazdálkodónak, a nemzetgazdaságban betöltött szerepe, valamennyi erdöt használó élőlény, ember, növény és állat érdekeinek figyelembevételével is meghatározó. A hazai erdészeti logisztika müködését nemzetközi összevetésben is tárgyaljuk annak érdekében, hogy a külföldi jó gyakorlatok hazai lehetséges adaptálását is elemezhessük.
\end{abstract}

\begin{abstract}
First the forest used to be the home of the people who later realised the importance and the different ways of utilisation of the woods. The wood accompanies the human life from the beginning to the end. The wood still plays important role nowadays in the ages of the different artificial and natural materials. The aim of our research is to demonstrate the operation and the management of a forestry company and the effectiveness of the logistics processes at this company. As a public owned forestry company its role in the national economy is still important and takes care of all the people, animals and plants interests living in the forest or using the forest itself. We analysed the functioning of the Hungarian forestry logistics in international comparison to investigate the potential adaption of the international best practices.
\end{abstract}

Kulcsszavak: erdőgazdálkodás, logisztika, fenntarthatóság

Keywords: forest management, logistics, sustainability

\section{Bevezetés}

Az erdő egyfelöl a bioszféra része, amely a Föld nagy részén kiterjedt, összefüggő állományokat alkot (Horváth, 2011), másfelöl egy olyan megújuló természeti erőforrás, amelynek sokoldalú felhasználási lehetőségeit a termőhelyi adottságok és az erdei vegetáció fejlődési üteme együttesen határozza meg. A faipar, az erdőgazdálkodás és a fafeldolgozás szempontjából meghatározó tényezőnek számít a technológiai innováció, a modern társadalmak értékváltása, valamint a termékek és szolgáltatások iránt állandóan változó kereslet. A fenti szempontok és hatások a vállalkozások üzletpolitikájára és jövőjére vonatkozóan is egyszerre jelentenek lehetőségeket és fenyegetettséget. Részben ennek a folyamatnak is köszönhetően az utóbbi évtizedekben az erdőgazdálkodás és a fafeldolgozás vezető szakembereivel szemben támasztott követelmények rendkívüli módon megnőttek, hiszen ma már mindenek elött közgazdasági és vállalatgazdasági ismereteket is magukban foglaló komplex tudásra van szüksége minden sikeres vezetőnek.

Mind az állami, mind a magántulajdonú erdészetekre jelentős hatást gyakorol a jogi és politikai környezet változása. A hatósági és a társadalmi feladatokat mindig a gazdasági célkitüzések kontextusában kell vizsgálni. Sem a vállalatvezető szakembereket (kezelö), sem az erdészeti üzemeket (hatóság) nem tekintik gazdasági szervezetnek. Mindez azért nem szerencsés, mert egy rendkívül komplex és modern gazdasági ágazat részei, amelyek más vállalkozásokkal állnak versenyben a 
beszerzési és értékesítési piacokon (Schmithüsen et al., 2013). Az eltérő vásárlói érdekek miatt az erdőgazdálkodás és fafeldolgozás eddigi értelmezési szemlélete megváltozott, amikor megszünt az ágazatok közötti határ. Ez a szemléletmód-váltás a hatékonyság növelését és költségmegtakarítást eredményez, növekvő vásárlásszámot generál és növeli a fatermékek és faipari termékek értékesítésének piaci esélyeit.

1.1. Az erdöterület megoszlása a világon, különös tekintettel Magyarországra

Az erdőgazdálkodás mértékétől és jellegétől függően hagyományosan három erdőtípuscsoportot határolhatunk el: az őserdőket, a gazdasági erdőket és az egyéb rendeltetésủ erdőket (Pápai, 2013a). A világ erdőterületeinek földrajzi megoszlását 1. ábra tartalmazza.

\section{1. ábra: Az erdőterület százalékos megoszlása a Földön 2014-ben}

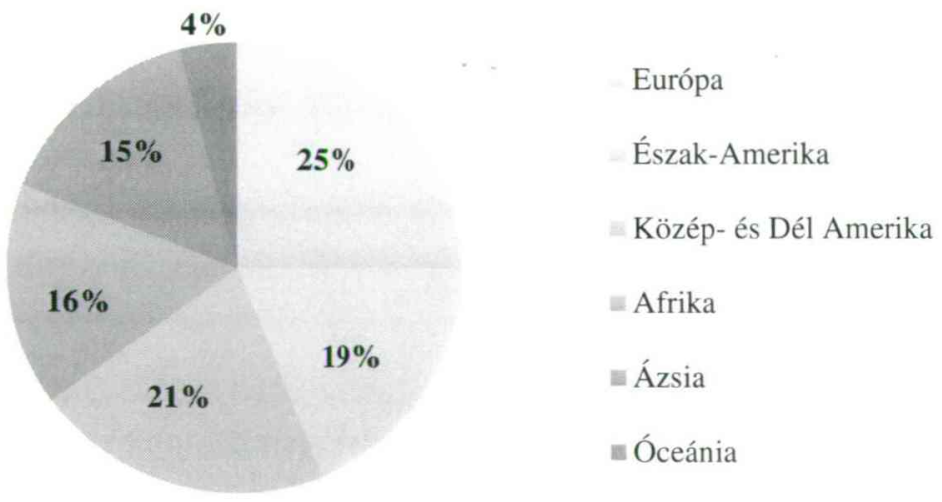

Forrás: Saját szerkesztés a FAO (2015a) adatai alapján (2017)

Ázsia csupán 15\%-ban részesedik a Föld erdőterületéből (1. ábra), míg Európa rendelkezik - az Orosz Föderációval együtt - a Föld erdőterületeinek 25\%-ával. Az egy lakosra jutó erdőterület az Ázsiára jellemző alig 0,1 hektártól az Európában kimutatott 1,4 hektáron, az Észak Amerikában mért 1,6 hektáron, Dél-Amerika 2,3 hektáros értékén keresztül 6,6 hektárig (Óceánia) terjed (FAO, 2015a). Az európai országok (beleértve az Orosz Föderációt is) szárazföldi területének 49\%-a, mintegy 1015 millió hektár az erdővel és egyéb fával borított terület (FAO, 2015b). A kimutatások szerint a tényleges erdőterület jelenleg kereken egy milliárd hektár, illetve a szárazföld 44\%-a. Ebből 809 millió hektár erdő jut az Orosz Föderációra, ez kb. a négyszerese az Európa fennmaradó területét borító erdőterületnek. Oroszországot leszámítva Nyugat-, Közép- és Kelet-Európában csaknem 200 millió hektárt tesz ki az összes erdőterület (FAO, 2015b). Az európai erdőterület mintegy 75\%-a található az Európai Unió 28 tagállamában. Az EU-28 összes területéből (420 millió hektár) 162 millió hektár (42\%) az erdỏ és egyéb állománnyal borított terület. Ebből 156 millió hektár a szükebb értelemben vett erdő. A fenti adatok tükrében az erdősültség átlagos területaránya így 42\%-ot tesz ki az EU-ban (FAO, 2015b). 
Magyarország (kontinentális, mérsékelt éghajlatának köszönhetően) a lomberdők zónájába tartozik. Mielőtt megkezdődhetett volna az emberiség tudatos tájformáló tevékenysége, hazánk több mint $85 \%$-át borította erdő. Az erdősültség megoszlása napjainkban megközelítőleg 21\% körül mozog Magyarországon (KSH, 2015a). A hazai fás társulások közül a legnagyobb területet az erdők foglalják el. Ezek élőhelyükön mindig zárótársulást jelentenek, legelterjedtebb típusként cserestölgyes erdeinket említhetjük. A több mint 2 millió hektárnyi erdő fafaj összetétel, egészségi- és természetességi állapot szempontjából nagyon változatos (2. ábra).

\section{2. ábra: Erdőalkotó fák megoszlási aránya Magyarországon 2015-ben}

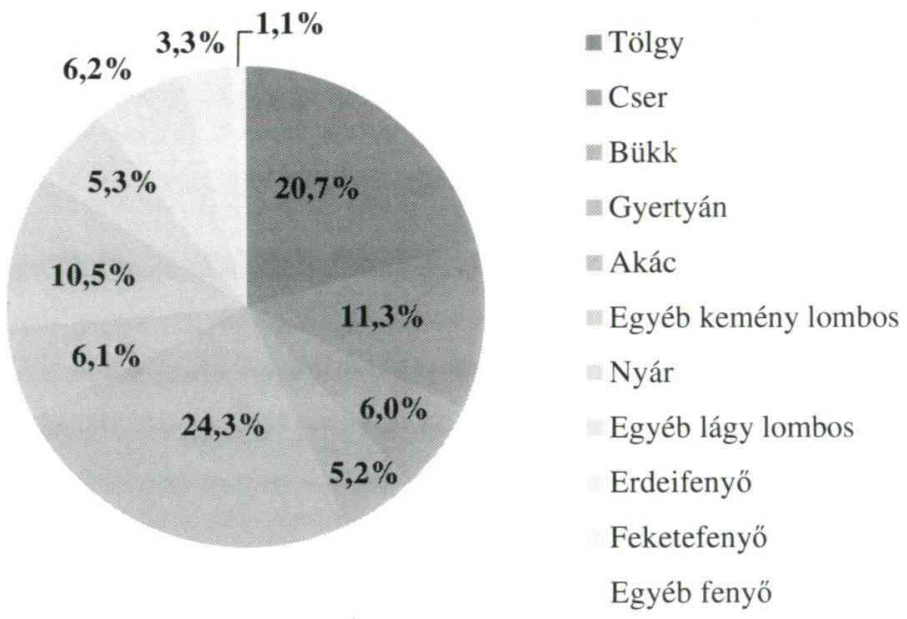

Forrás: KSH (2015b) adatai alapján saját szerkesztés (2017)

\subsection{Erdőgazdálkodás nemzetgazdaságban betöltött szerepe és ágazati irányítása}

Erdősültnek tekinthető hazánk területének több mint 1/5-e. Az erdökben végzett több évszázadnyi tudatos emberi tevékenységet, az erdők közcélú funkcióinak biztosítását, védelmét, az erdővagyon bővítését és az azok haszonvételének gyakorlására irányuló emberi beavatkozásokat összefoglaló néven erdőgazdálkodásnak nevezzük (Pápai, 2013b). Több funkciós agrárgazdaságunk egyik meghatározó eleme az erdőgazdálkodás. A rendszerváltást követően az erdőterületek egy része magánkézbe került, de a privatizáció ellenére is Magyarország erdővagyonának 50\%-ot meghaladó aránya állami tulajdonban áll (Égetö, 2013). Magyarország erdőterülete az elmúlt mintegy 90 évben fokozatosan emelkedő ütemben gyarapodott. A nagyarányú erdőtelepítéseknek és fásításoknak eredményeként az ország összesített erdőterülete ma már meghaladja az 1,93 millió hektárt. E terület fenntartása elképzelhetetlen lett volna a szakszerü erdőgazdálkodás hiányában. Az erdő három fő közérdekủ funkciói közül vizsgálatunk szempontjából a gazdasági funkció bír a legnagyobb relevanciával. Az erdő évezredek óta számos haszonvételi lehetőséget biztosít az emberiség számára, amelyek közül a faanyagtermelés a legfontosabb. 
Magyarországon körülbelül 1 millió hektárnyi erdő van jelenleg állami tulajdonban, amely terület 22 állami erdögazdaság között oszlik meg. Ezek a vállaltok gazdálkodnak ezeken a területeken, védik, örzik és gyarapítják az itt található állami erdővagyont. 2015-ben több mint 24000 ember foglakozott erdőgazdálkodással, ami a teljes foglalkoztatotti létszám 0,6\%-át tette ki. A bruttó hozzáadott érték 2014-ben Magyarországon 27081 milliárd forint volt, amelyből az erőgazdálkodás 60,5 milliárd forinttal részesült. Így a teljes mezőgazdasági szektor kb. 4,2\%-ot képvisel a bruttó hozzáadott értékböl, amelynek $0,2 \%$-a az erdőgazdálkodás részesedése (AKI, 2015).

\section{3. Értékteremtési folyamatok és anyagmozgatás a fahasználatban}

A fa értékteremtési lánca nagymértékü hatást gyakorol az erdőgazdálkodás és a fafeldolgozás gazdasági jelentőségére. A megújuló nyersanyagként létező fa termelésével és feldolgozásával járul hozzá a fenntartható fejlődés céljainak eléréséhez. Az erdőgazdálkodás és a faanyag-termelés decentralizáltan történik. A faanyag-termesztés és feldolgozás gazdaságilag realizálható értékteremtésének alapjai az erdőgazdálkodás és a fafeldolgozás közötti szerteágazó termelési és cserefolyamatok. Az értékteremtési lánc kezdete az erdöállományokban folytatott fenntartható gazdálkodás, amelyet az erdei fatermék faipari ágazatokban történő megmunkálása, feldolgozása, továbbá az abból keletkező beruházási és fogyasztási javak előállítása követ, amely javak alkalmasak a keletkező kereslet kielégítésére. A fa kitermelése maga a lánc kiindulási pontja, amelyhez a faipar különbözö ágazatainak értékteremtési folyamatai is kapcsolódnak. A termékek és szolgáltatások iránti teljes értékteremtést a felvevőpiacokon megnyilvánuló kereslet és kínálat irányítja. A kereslethez igazodó versenyképes termelés, értékesítés, marketing és logisztika döntő jelentőségü a vállalatok gazdasági sikere és az értékteremtés egészének mértéke szempontjából (Schmithüsen et al., 2013). A müszaki innováció folyamatos térnyerése, továbbá a beszerzési és értékesítési lehetöségek bővülése következtében a beszerzés, a termelés és az értékesítés területén vertikális és horizontális integráció alakul ki (Nábrádi-Nagy, 2007). A modern technológiának köszönhetöen az információáramlás az értékteremtési folyamatok kulcsfontosságú elemévé válik, de ugyanez a megállapítás az időtényező esetén is kiemelendő. A logisztikai rendszerek kialakítása során tipikusan sor szokott kerülni az áramlási és raktározási folyamatok összekapcsolódására. Mindez grafikusan raktárak, más szóval raktározási pontok hálózataként írható le. A hálózatok komplikáltságuk szempontjából a viszonylag egyszerüektöl az igen összetettekig nagyfokú diverzitást mutatnak (Knoll, 2001).

A fa értékteremtési lánc logisztikai koncepciójának megfelelő integrációja a közép-európai régióban - a skandináv vagy észak-amerikai viszonyokhoz képest még gyermekcipőben jár. Az erdötulajdonosok és a fafeldolgozó üzemek között fennálló kapcsolat nem ritkán még mindig a hagyományos vevő-szállító viszonyt tükrözi. Ilyen esetekben az értékteremtő lánc következő fokainak megfelelő bevonása nélkül történik az erdőgazdálkodás termeléstervezése és irányítása. Az erdei fatermékek sokszor a push (nyomó) elv termelés-tervezés alapján, 
kínálatorientáltan kerülnek a piacra (Schmithüsen, 2004). Azonban a különbözö értékteremtési láncszemek hatékony integrálásáról nem mindig lehet beszélni ott, ahol a termelés elsősorban a vevői igényekhez kíván alkalmazkodni. A nemzetközi szinten müködő integrált vállalatok esetén az értékteremtési lánc folyamatorientált menedzsmentje lényegesen elörehaladottabb. A különböző értékteremtési láncszemek integrálásának előfeltétele, hogy a logisztikai partnerek rendelkezzenek a döntéshez szükséges, az igények iránti keresleti viszonyokkal, valamint a rövid- és középtávon rendelkezésre álló információkkal (Chikán-Demeter, 2006). Napjainkra már nem a különböző folyamatok és az azokhoz kapcsolódó anyagmozgatási rendszerek jelentik az újdonságot, hanem a rájuk épülő, támogató logisztika tudománya, filozófiája, ami az ellátás, termelés, elosztás irányításának rendszerszemléletú megközelítését feltételezte (Horváth-Karmazin, 2014). Az elmúlt évtizedek gazdasági növekedése, az infrastruktúra és a gépesítés ugrásszerü fejlődése az anyagmozgatás reformját is előidézte. Az anyagmozgató rendszerek nem létezhetnek önállóan, csakis a termelési folyamatokhoz kapcsoltan, hiszen mindig valamilyen termelési, ellátási, elosztási vagy áruszállítási rendszert szolgálnak ki (Szegedi-Prezenszki, 2010).

Az erdészeti anyagmozgatásra jellemző kezdő müvelet a koncentráció, amely során a szétszórtan elhelyezkedő faanyag összegyüjtésére kerül sor. Az erdészeti anyagmozgatás záró múvelete pedig a disztribúció, vagyis az eladásra szánt faanyag szétosztása az átvevők között. Napjainkban a fahasználat és faanyag-értékesítés során egyre több olyan eset kerülhet vizsgálatunk látókörébe, amikor a koncentráció munkamüvelete után nem következik disztribúció, mert a faanyag egy átvevőhöz kerül (pl.: az erdei apríték erőmüvi felhasználásakor) (Rumpf, 2016). A faanyagmozgatás sikeres lebonyolításához a különböző alrendszerek (ember; eszköz- gép; szállítópálya) és részrendszerek (információs és irányítási) összehangolt együttmüködésére van szükség.

Az első alrendszerbe tartozó ember a kézi- és gépi anyagmozgató rendszerek esetében jelen van a folyamat során, míg az automatizált termelésben személyes jelenlétére nincsen szükség. A kézi anyagmozgatás a kézi közelítés során valósul meg, ahol az ember fizikai erejét állítja a logisztikai folyamat szolgálatába. Ennél fizikailag - sokkal könnyebb, ám intellektuálisan nagyobb kihívást és szakértelmet igényel a gépi anyagmozgatás, hiszen a gépi anyagmozgató rendszereknél már csak a tevékenység végrehajtásához szükséges irányítási és vezérlési feladatok ellátásában van az emberi erőforrásnak szerepe. Emellett ki kell még emelni az állati és a gravitációs erô által végzett anyagmozgatást (akár közvetlenül, akár a közvetett alkalmazást feltételező gépek hajtása útján), valamint a vízi közelítést és szállítást, melyek napjainkban ugyan nem jellemzöek, de a múltban ezek is fontos anyagmozgató rendszerek voltak (Rumpf, 2016). Az eszköz - gép alrendszerhez soroljuk a faanyagáramlást megvalósító, illetve annak megvalósításában közremúködő kézi anyagmozgató eszközöket, anyagmozgató kisgépeket, anyagmozgató gépeket, valamint az ezeket kiegészítő különböző segédeszközöket is. Az erdészeti anyagmozgatás szakaszosságát többnyire az elérhető úthálózat hibái okozzák. Mivel a legtöbb út nem rendelkezik állandó szilárd útburkolattal, ezen utak 
állapota nagyban függ az időjárás hatásaitól. Ez a tényezỏ szabja meg azt is, hogy mekkora mennyiségü, méretü, minőségü anyagot milyen sebességgel és milyen távolságba tudnak a kitermelők optimálisan mozgatni. Ezek a paraméterek szabják meg, hogy milyen típusú (teherbírású, raksúlyú) eszközzel lehet az anyagmozgatást a legnagyobb hatékonyággal elvégezni. A szállítás szakaszossága attól is nagyban függ, hogy hányszor kell átrakodni a faanyagot szállítás során. A cél a szakaszok és ezzel együtt az átrakások számának csökkentése annak érdekében, hogy a hatékonyság a költségek csökkentése mellett is növelhetö legyen (Rumpf, 2016). Az erdőhasználati munkák hatékonyságát az agyagmozgatás kivitelezést megelőző, tudatos megszervezésével lehetne növelni. A fahasználat során végzett egyes szállítási feladatokat rendkívül jól jellemzik az alkalmazott áruszállítási struktúrák. Ugyanakkor okvetlen kiemelendő, hogy ezeknek a rendszereknek a felvázolásában a fahasználati anyagmozgatás egyes mủveletei, vagyis az előközelítési, közelítési, illetve kiszállítási és szállítási feladatok nem minden esetben választhatók szét.

\section{Anyag és módszer}

A kutatás elökészítése során primer és szekunder adatgyüjtést végeztünk. A primer adatgyüjtés lehetőségét az Északerdő Zrt. teremtette meg, akik biztosították számunkra az elemzéshez szuikséges adatokat. A kutatás során strukturálatlan interjúk is készültek. Több alkalommal készült strukturálatlan interjú a sátoraljaújhelyi kerületet vezető erdésszel, a vállalat különböző ágazatainak vezetöivel és az erdészekkel is melyek segítségével információhoz jutottunk a vállalatról, a logisztikai folyamatokról és faanyagmozgatásról. Ennek révén elegendő ismeretanyagra tettünk szert, hogy a kutatási témát el tudjụk kezdeni és új irányba tudjuk azt mozdítani.

A kutatás során használt módszertan másik fó formája az esettanulmány volt. A céggel kialakult kapcsolatnak köszönhetöen számos tevékenységbe és erdőgazdálkodási folyamatba betekintést nyerhettünk, valamint a rendelkezésünkre bocsátották az eredménykimutatást és mérleget 2007-2015 évek között. Ahhoz, hogy biztonsággal elemezzünk egy vállalkozást, elengedhetetlen, hogy ismerjük mind a hozam, mind pedig a termelési érték oldalt. A kapott adatok segítségével hatékonysági mutatókat, valamint a gazdaság költség- és jövedelemviszonyait elemeztük.

A szekunder anyaggyüjtés keretében került sor a hazai és nemzetközi szakirodalom, kutatási jelentések, tanulmányok és szakcikkek feldolgozására. Ezek közül kiemelendö a Food and Agriculture Organization of the United Nations (FAO), a Központi Statisztikai Hivatal (KSH) adatbázisa és az Agrárgazdasági Kutató Intézet adatai, dokumentumai és kiadványai.

\section{Eredmények}

\subsection{Az Északerdö Zrt. bemutatása}

Hazánkban 22 állami erdőgazdaság található. Ezek közül hazánk északkeleti részén elhelyezkedő, változatos felszíni formákkal és élővilággal rendelkező 
erdőgazdasághoz tartozik az Északerdő Erögazdasági Zrt. A társaság közel egy évszázados múltra tekint vissza, már a XVIII-XIX. században uradalmi erdőgazdálkodás folyt ezen a területen. A társaság 1993-tól vált 100\%-ban állami tulajdonú részvénytársasággá. Az Északerdỏ Zrt. Magyarország északi részén, Borsod-Abaúj-Zemplén megyében helyezkedik el. A társaság összes kezelésében lévő terület 107 ezer hektárt tesz ki, ebböl 102 ezer hektár, ami ténylegesen erdőterület, ami az ország erdöterületének körülbelül 6\%-át jelenti.

A társaság fő tevékenységi köre az erdő- és vadgazdálkodás, fafeldolgozás, erdőfelújítás, mag- és csemetetermesztés, fakitermelés, erdőgazdálkodással összefüggő szolgáltatások, valamint közjóléti tevékenység.

A gazdálkodást a 10 évre szóló erdőterv alapozza meg. A faállomány $45 \%$-a tölgy, 24\%-a bükk, 21\%-a cser, akác, gyertyán, 2\%-a lágy lombos, $8 \%$-a fenyves. Az Északerdő Zrt. összes gazdálkodási területének 46\%-a védett, melyböl $29 \%$ nemzeti park és 17\% tájvédelmi körzet. A kezelése alatt álló területek közül 83,2 ezer hektár tartozik a Natura 2000 (Az Európai Unió ökológiai hálózata) védettségbe, valamint egyéb természetvédelmi korlátozásba közel 34,6 ezer hektár esik.

A társaság filozófiáját jól példázza, hogy a fokozatos felújító vágás teszi ki a kitermelési mód közel 60\%-át, továbbá meghatározó jelentőségủek a törzskiválasztó gyérítés és a tisztítási müveletek is. A vállalkozás erdősítéseiben elönyben részesíti az öshonos fö- és elegyfafajokat. Erdeiben a felújítási, nevelési és fakitermelési munka szakaszban egyaránt a természetest megközelítő változatosság létrehozására törekszik. Ez az állapot a gazdag és harmonikus erdei életközösség kialakulásának feltétele, melynek biztosítását és megőrzését a Társaság alapfeladatának tekinti. A részvénytársaság a fentiek jegyében - kíméletes technológiák alkalmazásával évente átlagosan 150-200 ha mesterséges erdősítést végez, 600-700 ha új erdőt ad át, és $6000-7000$ hektáron végez ápolási munkát.

A folyamatos és akadálymentes erdőgazdálkodás végzése érdekében az állandó dolgozók mellett szükség van ideiglenes munkaerö bevonására is. Ezt képzett és betanított fakitermelő brigádokkal oldják meg. 2015-ben a foglalkoztatottak száma 328 fö volt, mely 2007-töl folyamatosan csökkenö tendenciát mutat. A társaság folyamatosan vesz részt közfoglalkozatási programokban, így növelve a fizikai dolgozók számát további 100-600 fövel (I1).

3.2. A vizsgált vállalat komplex elemzése

A társaság rendszeresen vezet fökönyvi kivonatot, valamint erdészeti és ágazati eredménykimutatást a számviteli törvénynek megfelelỏen. A vizsgálataink alapján elmondható, hogy a forgóeszközök aránya 2011-ben és 2012-ben viszonylag magas volt. A 2013. évben a vállalat több mint 2100000 Ft értékvesztést számolt el vevőkövetelésre. A vállalat befektetett eszközeinek értéke növekvő tendenciát mutat 2011-töl, ami egyértelmủen leolvasható, ha a 2011 -es évhez viszonyítunk. A társaság a befektetett eszközeinek az értékét megduplázta, köszönhetően beruházásainak.

A befektetett eszközök fedezete a vizsgált 9 évben megfelelö volt, hiszen a mutató értéke a végig jelentősen $100 \%$ feletti az értéket mutatott. 2007-től egészen 2012-ig folyamatosan növekvő tendenciát mutatott, 2013 és 2015 között csökkent. 
A tőkeerősségi mutató a 30\%-os határt a vizsgált években jóval meghaladta. A 2007-től 2009-ig növekvő tendenciát mutat, majd 2009-től a mutató százalékos értéke csökkenni kezd. Ez egyértelmüèn a források növekedésének tudható be. A vizsgált 9 évben nagyjából 2,5 milliárd forinttal nött az összes forrás értéke. Ez visszavezethető a céltartalék képzésekre és a kötelezettségek értékének folyamatos emelkedésére. A tőke multiplikátor esetében a csökkenő tendencia lenne ideális, azonban a vizsgált időszakban ez a mutató növekvő tendenciát mutat. Ennek oka az eszközérték váltakozása.

A kötelezettségek aránya mutató arra ad választ, hogy a források között milyen mértékü az idegen források jelenléte. A vizsgált időszakban a saját források aránya jóval magasabb, mint az idegen tőkéé, a mutatók a vizsgált években a kritikus $70 \%$ alatt mozogtak.

A gazdálkodás eredményességének fontos mutatója, hogy hogyan alakult a vállalkozás értékteremtő képessége. A vállalatok úgy növelhetik hatékonyságukat, hogy vagy a termelési értéket növelik, vagy a termelési költséget csökkentik. Az elemzők akármelyik input tényezőre mérhetnèk hatékonysági rátát, erre azért van szükség, hogy megtudjuk, hogy a vállalat milyen hatékonyan használja ki az inputjait, és emellett olyan kibocsájtást érjen el, hogy a vállalat számára értékes legyen (Kaplan-Atkinson, 2003).

A vállalkozások müködésének eredményességét a jövedelmezőségi mutatók alapján vizsgáljuk. Az erdő egy gazdaságosan fenntartható erőforrás. Egy hagyományos erdőgazdálkodás faanyagtermelés centrikus, így a fỏ hozamok primer erdei választékként keletkeznek. A fö termék tehát maga a fa, melléktermékek között mindenképpen értékelendő a vadászati jog is (Pápai, 2013b).

$\mathrm{Az}$ Északerdő Zrt. termelési költségeit 2007-2015 között vizsgáltuk. Elmondható, hogy 2012-ben történt egy eröteljes növekedés a termelési költségben ez a személyi ráfordítások hirtelen emelkedésének tudható be ( 630 millió $\mathrm{Ft})$, ami a 352/2010 Kormányrendelet miatt következett be. E rendelet szerint 2011. évi adójárulékváltozások miatt bekövetkezett nettóbér csökkenésére vezettek be egyfajta „bérkompenzációt”.

A nettó jövedelem értéke 2007 és 2015 között minden évben pozitív elöjelü volt, azonban a vállalat volumenéhez képest kis profitot termel ( 1 . táblázat). Az Északerdő Zrt. jelentős termelési értékkel és termelési költséggel rendelkezik, ezek tükrében a nettó jövedelem alacsonynak mondható. A jövedelemszint a gazdaság növekedése, a vállalkozások létesítése és fejlỏdése, versenyképessége miatt is fontos. A megszerzett jövedelmek egy részének központosítása (adók, járulékok stb.) a kormányzat számára költségvetési forrást biztosít. A költségszint mutatja, hogy az árbevétel mekkora hányadát emésztik fel a vállalati költségek. A költségszint az összes költség és a termelési érték hányadosa. Az egységnyi termelési értékre jutó költséghányadot mutatja meg. 
1. táblázat: A nettó jövedelem, a költségarányos jövedelmezőség, a jövedelemszint és a költségszint alakulása 2007-2015 között

\begin{tabular}{|l|c|c|c|c|}
\hline Év & $\begin{array}{c}\text { Nettó } \\
\text { jövedelem } \\
(\mathbf{e F t})\end{array}$ & $\begin{array}{c}\text { Költségarányos } \\
\text { jövedelmezöség } \\
(\mathbf{\%})\end{array}$ & $\begin{array}{c}\text { Jövedelemszint } \\
\mathbf{( \% )}\end{array}$ & $\begin{array}{c}\text { Költségszint } \\
\mathbf{( \% )}\end{array}$ \\
\hline $\mathbf{2 0 0 7}$ & 50327 & 1,23 & 1,22 & 98,78 \\
\hline $\mathbf{2 0 0 8}$ & 91084 & 2,35 & 2,30 & 97,70 \\
\hline $\mathbf{2 0 0 9}$ & 49338 & 1,28 & 1,26 & 98,74 \\
\hline $\mathbf{2 0 1 0}$ & 50327 & 1,23 & 1,22 & 98,78 \\
\hline $\mathbf{2 0 1 1}$ & 32134 & 0,79 & 0,78 & 99,22 \\
\hline $\mathbf{2 0 1 2}$ & 38866 & 0,82 & 0,82 & 99,18 \\
\hline $\mathbf{2 0 1 3}$ & 55339 & 1,17 & 1,16 & 98,84 \\
\hline $\mathbf{2 0 1 4}$ & 48938 & 0,97 & 0,96 & 99,04 \\
\hline $\mathbf{2 0 1 5}$ & 147210 & 3,03 & 2,94 & 97,06 \\
\hline
\end{tabular}

Forrás: Saját számítás az Északerdö Zrt. adati alapján (2017)

\subsection{Logisztika az erdőgazdálkodásban}

Az EU-csatlakozás után egyszerüsödött a mobilitás, melynek következtében az ellátási lánc a határokon keresztül is átívelt. Ennek hatására a verseny élesedett, a hazai vállalkozásoknak már a többi tagállammal is lépést kellett tartaniuk. A mai világban a globális és bỏvített ellátási láncra azért van szükség, mivel számos új gazdasági-, technikai- és környezeti tényező jelenik meg, melyek egy új „SC-Gglobális ellátási lánc" kialakítására befolyással vannak.

A logisztikai módszerek magyarországi alkalmazása az erdőgazdálkodásban máig, viszonylag elhanyagolt terület. Az erdőgazdálkodásban a termeléstől az értékesítésig számos folyamatelem megtalálható. Alapvetően ez egy logisztikai lánc, melyben az erdőgazdálkodók, a fafeldolgozási ipar és a szolgáltatók sokasága anyagi-, élömunka- és értékáramlást hoz létre. Elsődleges lépés a faanyag „elóállítási” helyéröl történő elszállítása, ami az egyik legjelentősebb ráfordítási igénnyel bír. Elmondható, hogy az anyagmozgató eszközök kihasználásában jelentős eltérések mutatkoznak. Az áruk elosztási folyamatait tekintve, ezen belül is az áruszállítási útvonalak és azok jellege (közút, vasút), nagyon fontos döntési tényező. Az átrakodások számát általában a termeléstől a feldolgozásig vagy a fogyasztóhoz történő eljutásig számítjuk. Ez a szám a logisztikai költségeket, így termék árát is nagyban befolyásolhatja. Fontos tényező az adott folyamat egy-egy szakaszának átfutási ideje, hiszen alapvető elvárás, hogy a szállítmány minél rövidebb idő alatt jusson el a rendeltetési helyére. Az idő-faktor egy export üzlet esetén, a marketing és a kereskedő jó kooperációja révén közrejátszik abban, hogy a termék a megfelelö helyen legyen a megfelelő időben, ezáltal megelőzzék az esetleges konkurenciát. Végeredményben döntő fontosságú, hogy az ellátási lánc költség és egyéni ráfordítások a lehető legkisebbek, de mindenképpen céljainkhoz mérten optimálisak legyenek. 
Ezen ágazatban is fontos a versenyképességet elősegítő tényezők, mint a minőségmegóvás, a piacra jutás idejének csökkentése, melyhez a logisztikai rendszerek segítségnyújtása elengedhetetlen. Ebben a közeledési útvonal és eszközei megválasztásának jelentős szerepe van. Köztudott, hogy közúton gyorsabban lehet haladni, mint vízen vagy vasúton, valamint jellemző a „háztól-házig” terjedő szállítás. A vízi faszállítás hazánkban nem meghatározó (jóval a „skandináv és észak-amerikai színvonal" alatt van), ez elsősorban a kikötők hiányára vagy a meglévők gyenge infrastrukturális ellátottsága vezethető vissza. A vasúti szállításban is vannak problémák, így például kevés a faanyag szállítására alkalmas eszközpark, az átrakodás gépesítésének fejlesztésében is akad tennivaló (Knoll, 2010).

\section{3. ábra: A faanyag áramlásának folyamata egy konkrét példán keresztül}

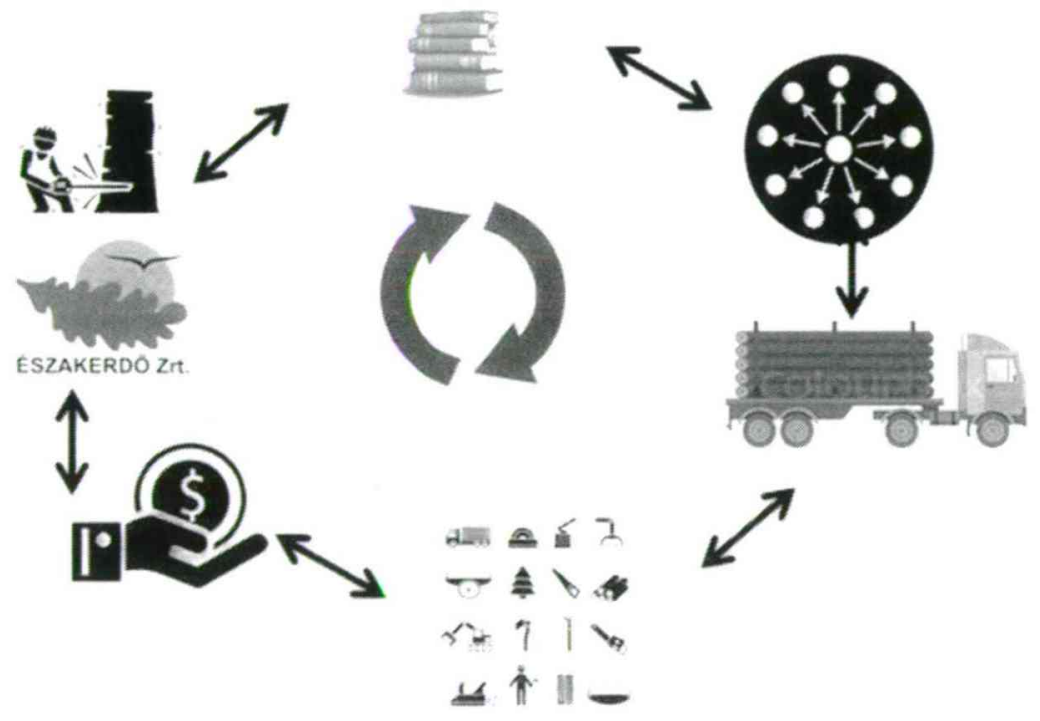

Forrás: Saját szerkesztés (2017)

Mint minden állami erdőgazdaság, így az Északerdő Zrt. is 10 éves erdőtervek alapján kezdi meg a faanyag kitermelését. A 3. ábra egy faanyag áramlási folyamatot mutat be, mely a sátoraljaújhelyi kerületben történő termelési tevékenységek egy kis részét teszik ki. E termelési folyamatok megkezdésére hatással vannak a korábban említett törvényi szabályzások. A kerület tagokra és részletekre van felosztva, ezen belül is meghatározott, hogy milyen fafajt és milyen mennyiségben lehet kitermelni. A logisztikai szervezését itt is, akárcsak a mezőgazdaságban, az időjárás nagymértékben befolyásolja. Az adott helyre történő szállítást nehezítheti a burkolatlan utak erőteljes hiánya. A fa a kitermelés után szétszórtan helyezkedik el az erdőben, ezeket egy helyre kell hordani, ahol minőség és rendeltetés szerint osztályozzák, majd elindul a disztribúciós folyamat. 
A faanyag koncentrációját és rendeltetés szerinti válogatását követően már a hegyen megkezdődik annak szállítása, ahol különböző gépi erőforrások segítségével megrakodnak egy szállítóeszközt. A szállítójármü a kerületből megrakodva a sátoraljaújhelyi vasútállomásra szállítja az anyagot, ahol az erdész által elözetesen megrendelt vagonok várják az árut. A szállító jármủ EKÁER (Elektronikus Közúti Áruforgalom Ellenőrzö Rendszer) köteles abban az esetben, ha nem végfelhasználóhoz viszi a faanyagot. Ezután megkezdődik a faanyag rakodása, ami hidraulikus emelővel történik. A vagonok faanyaggal való feltöltése szabályokhoz kötött, amit a vagonvizsgálók szigorúan ellenöriznek. Az adott példában minőségi bükk fürészárut szállítottak az ország déli részén található fürészüzembe. A faanyagot 4 minőségi osztályba sorolják, majd eszerint fizetik ki a köbméterenkénti árat euróban. A nyomon-követhetóségben és az azonosíthatóságban nagy szerepet játszik a vonalkóddal és cégnévvel ellátott jelölöcédula, melyet minden egyes szállítandó farönkre elhelyeznek a vevők. Az egész folyamat a kivágandó fák kijelölésétől egybegyűjtéséig, a rakodástól egészen az elszállításig a kerületvezető erdész felelősségteljes felügyeletével történik.

\section{Következtetések, javaslatok}

$\mathrm{Az}$ erdő speciális termelési tényező és a vállalat, mint állami tulajdonú társaság elsődleges célja nem a profitmaximalizálás, hanem az erdőtörvény betartása és a tulajdonos (állam) által elvárt, a társadalom számára ,ingyenesen” jutatott szolgáltatások megvalósítása.

Célunk a vállalat elemzése volt komplex vizsgálat útján. A vizsgált években (2007-2015) a vállalat termelési értéke - a hatalmas termelési költségei ellenére mindig magasabb volt, tehát értéket teremtett. A nettó jövedelme az évek alatt folyamatosan változik, de mindig jóval a fedezeti pont felett helyezkedik el. A befektetett eszközeivel - melyek a vállalatot éveken keresztül szolgálják - a vállalat kiválóan gazdálkodik, hiszen a befektetett eszközök fedezete mutató a definíció szerint elfogadható $100 \%$-ot mind a vizsgált 9 évben nagymértékben meghaladja. A vállalat tőkeerős alapokon nyugszik, amit a tőkeerösségi mutató bizonyít, itt a kedvező 30\%-ot szintén jelentősen meghaladja minden vizsgált évben.

Véleményünk szerint a további stabil müködés fenntartásához az alábbiak átgondolása szükséges:

- a meglévő vevőkör megtartása, újabb vevők keresése,

- a környezetkímélő vágásmódok további alkalmazása,

- az erdei turizmus iránti növekvő igény kihasználása,

- további úthálózat létesítése, kamionfordulókkal,

- szoláltatások fejlesztése (pl.: vadászturizmus).

A fahasználat során végzett szállítási feladatok kapcsán fontos megemlíteni, hogy a faanyagmozgatás egyes müveletei (az elöközelítés, közelítés, kiszállítás és szállítás) nem minden esetben választhatóak szét. A faanyagszállítás a teljes termelési költség 50-60\%-át teszi ki. A szállítások során gyakran előfordulhatnak „vészhelyzetek” (forgalmi akadályok, szélsőséges időjárás stb.) amelyek nem teszik lehetővé a ,just in time" megvalósítását. Meglátásunk szerint több módszerrel 
javítható a vállalatnál folytatott termelőtevékenység hatékonyságának növelése. Célszerủ volna csökkenteni a készletezett faanyag mennyiségét, továbbá a faanyag érkezési idejét elöre eltervezni, hiszen így csökken a várakozási idő, ráadásul az egy helybe gyưjtött, szállítandó faanyag helyének pontos ismerete mérsékli az üzemanyag fogyasztást és az üresjárati időt. A szállítási útvonal előzetes megtervezésére a távolság és egyéb felmerülő költségek függvényében kerülhet sor, de indokolt további, burkolt erdei úthálózat létrehozása, ezzel is fejlesztve a meglévő infrastruktúrát. Hasznos volna a többszakaszos, több jármüvet igénylő anyagmozgatást egy jármüvel ellátni.

Az átfutási idő csökkentése korszerü informatikai eszközök alkalmazásával is növelhetö. $\mathrm{Az}$ lehetséges fejlesztések közül kiemelendőek az elektronikus mérőeszközök, az RFID (Radio-Frequency Identification) íróval és olvasóval ellátott vevőegységek (pl.: PDA) a rádiófrekvenciás rönkazonosításhoz és nyomon követhetőséghez, a HD (high definition) kamerák használata (pl.: készlet felmérésre), az okos telefonokon futtatható alkalmazások (pl.: rönkköböző, rönkátvevő, becslö), a fahasználati tervezö, optimalizáló és ellenörző programok használata, de célszerü volna a nyilvántartási rendszer fejlesztése, a vonalkódos rönkkövetés, a saját géppark bővítése, egy fedett faanyagtároló építése és a hitelesített kamion-mérlegelö rendszer kialakítása.

Az Északerdő Zrt.-nél megfigyelhető egy, lassú, de folyamatos korszerűsítő fejlödés. A technika fejlödése megállíthatatlan és elkerülhetetlen, előbb-utóbb minden ágazatban meghatározó jelentőségü lesz a modern informatikai háttér. A cég jó úton halad, de még hosszú az út a skandináv vagy az észak-amerikai fejlettségi szint eléréséig. Magyarországon a fahasználati logisztika napjainkban még gyerekcipöben jár, de törekvési kísérletek már megvannak és gyakorlati alkalmazásuk is megkezdődött.

\section{Irodalomjegyzék}

AKI, KSH (2016): Agrárgazdasági statisztikai Zsebkönyv, 2015. Agrárgazdasági Kutató Intézet, Budapest, 125 p. (doi 10.7896/zsk.1501)

Chikán A., Demeter K. (2006): Az értékteremtö folyamatok menedzsmentje - Termelés, szolgáltatás, logisztika. Aula Kiadó Kft.

Égető G. (2013): Erdészeti Gazdaságtan. Nemzeti Agrárszaktanácsadási, Képzési és Vidékfejlesztési intézet, Budapest, 181.

FAO (2015a): FAO Statistical Pocketbook 2015, <http://www:fao.org/3/a-i4691e.pdf>

FAO (2015b): Forestry Production and Trade, <http://www.fao.org/faostat/en/\#data/FO>

Horváth A., Karmazin Gy. (2014): Nemzetközi közúti árufuvarozás és szállítmányozás. Akadémiai Kiadó, Budapest

Horváth S. (2011): Vállalkozások fejlödése az erdögazdálkodásban, Doktori (PhD) értekezés, Nyugat-magyarországi Egyetem, Erdőmérnöki Kar, Sopron, 146.

Kaplan, S. R., Atkinson A. A. (2003): Vezetöi üzleti gazdaságtan. Panem-Business Kft., Budapest, 709.

Knoll I. (2001): Logisztika a 21. században. KIT Képzőmüvészeti Kiadó Kft.,

Knoll I. (2010): Interdiszciplináris logisztika a gazdaságpolitikában. 2. bõvített kiadás. Budapest, 2010

KSH (2015a): Földhasználat müvelési ágak és gazdaságcsoportok szerint, <http://www.ksh.hu/docs/hun/xstadat/xstadat_eves/i_omf001b.html>. (2017.02.21.) 
KSH (2015b): Fakitermelés fafajcsoportok szerint, <http://www.ksh.hu/docs/hun/xstadat/xstadat _eves/i_ome003b.html $\geq$

Nábrádi A., Nagy A. (2007): Vállalkozások mũködés az Európai Unióban. Szaktudás Kiadó Ház, Budapest

Pápai G. (2013a): Erdőgazdálkodás Kézikönyv erdõtulajdonosoknak. Mezőgazda Kiadó, Budapest, 359.

Pápai G. (2013b): Versenyképes erdógazdálkodás és fatermesztés. Mezőgazda Kiadó, 320.; 160-162. Rumpf J. (2016): Erdöhasználat. Mezögazda Kiadó, Budapest.119-271.

Schmithüsen, F., Kaiser, B., Schmidhauser, A., Mellinghoff, S., Kammerhofer, A. W. (2013): Entrepreneurship and Management in Forestry and Wood Processing

Schmithüsen, F. (2004): Role of Land Owners in New Forest Legislation

Szegedi Z., Prezenszki J. (2010): Logisztika-Menedzsment. Kossuth Kiadó Budapest

I1: <http://www.eszakerdo.hu/magyar/menu/ceginfo_uj.htm $\geq$ 